УДК 130

Бондар Н. О., Осіпов О. М.

doi: 10.32620/gch.2018.3.09

\title{
СОЦІАЛЬНО-ЦІННІСНА КОНЦЕПЦІЯ ІНЖЕНЕРНОЇ ДІЯЛЬНОСТІ
}

\begin{abstract}
Розглянуто соціально-цуіннісну конщепцію інженерної діяльності в межах філософського концепту постсучасності. Показано, щзо інструменталістський, техніцистський підхід до навчання майбутніх інженерів не лише призводить до суттєвих деформацій особистості фахівия, але й створює серйозні проблеми в розвитку суспільства, що трунтується на техногенному перетворенні середовища.
\end{abstract}

Ключові слова: інженерна діяльність, сочіально-иуіннісна концепція.

The social value concept of engineering activity within the framework of the philosophical concept of postmodernity is considered in the paper. It is shown that the instrumentalistic, technicalist approach to training future engineers not only leads to significant deformations of the specialist's personality, but also creates serious problems in the development of a society based on the technogenic transformation of the environment.

Keywords: engineering activity, social value concept.

Рассмотрена социально-ценностная концепџия инженерной деятельности в рамках философского конщепта постсовременности. Показано, что инструменталистский, техницистский подход к обучению будущии инженеров не только ведет к существенным деформациям личности специалиста, но и создает серьезные проблемь в развитии общества, основанного на техногенном преобразовании среды.

Ключевые слова: инженерная деятельность, сочиально-ценностная концепџия.

Усі наявні моделі аналізу цілей і завдань інженерної діяльності умовно можна поділити на інструменталістські, або інженерні, які розглядають «інженерну діяльність саму по собі»: етапи розвитку, закономірності виникнення техніки й інженерної діяльності; і соціогуманітарні, які розглядають «інженерну діяльність для нас»: як інженерна діяльність впливає на людину й суспільство, які трансформації відбуваються 3 людиною в результаті розвитку техніко-технологічної сфери. Філософія техніки в іiі інструменталістских концепціях є, з одного боку, спробою техніків і інженерів виробити філософію своєї професійної сфери. 3 другого боку, філософія техніки в соціогуманітарних концепціях становить сукупність зусиль учених-гуманітаріїв, що осмислюють техніку як предмет міждисциплінарних рефлексій.

Мета пропонованої статті - розглянути філософські основи соціально-ціннісних підстав сучасної інженерної діяльності в постіндустріальному суспільстві.

Найбільш ефективний шлях аналізу сутнісних підстав інженерної діяльності звернення до традиції філософії техніки. Опубліковано оригінальні праці в цій галузі як вітчизняних, так i зарубіжних авторів, зокрема В.Г. Горохова, Б.І. Козлова, П. Козловського, Х. Ленка, Н.M. Мамедова, К. Мітчема, Х. Ортеги-і-Гассета, 
А.Н. Павленко, В.М. Розіна, М.А. Розова, В.С. Стьопіна, П.А. Флоренського, М. Гайдепера, М.Л. Шубаса, К. Ясперса та ін.

Видатною постаттю в дискусіях із проблем філософії техніки й інженерної діяльності як до Другої світової війни, так і безпосередньо після неї був Ф. Дессауер [3]. Він стверджував, що сутність техніки полягає не в промисловому виробництві, а в самому акті технічної творчості. Л. Мемфорд [7], використовуючи власну концепцію людської природи, уперше подав розгорнутий аналіз широкого кола проблем «механічної цивілізації». Він підкреслював, що сутність людини не матеріальна творчість, а відкриття й інтерпретація. Філософія техніки Х. Ортеги-і-Гассета спирається на його ідею про людське життя. Людина є «технічною істотою» на тій підставі, що вона $є$ не частина природи, а носій певної ідеї, здатності інтерпретувати, пояснювати природу [10]. М. Гайдеггер стверджував, що не техніка є прикладною наукою, а науку слід розглядати як теоретичну техніку. Виходячи з цієї тези, учений формулює питання: хто або що є причиною технічного відкриття світу як чистого об'єкта? На його думку, «за спиною» сучасної техніки як здатності відкриття стоїть щось, що вважає світ і кидає йому виклик. Це щось М. Гайдеґгер називає Gestell [4]. Ця категорія фіксує трансцендентальну передумову сучасної техніки й інженерної діяльності. Він надає цьому терміну глибокий філософський зміст, який виражає сукупність ціннісних орієнтацій, що спрямовують людство, кидають йому виклик, звуть його до розкриття непізнаного. Gestell не є частиною техніки, воно є тією настановою, яка перебуває в субстанціальних підставах сучасної техніки, перебуває всередині технічної та інженерної діяльності $[4,28]$. Сучасний інженер - це людина, здатна генерувати ідею, утілювати іï в проекті, займатися експлуатацією технічних об'єктів.

Мета інженерної діяльності - розроблення засобів, методів, прийомів перетворення середовища в техносферу. Результатом такої праці $є$ виробництво. Інженерна діяльність є ланкою, що об'єднує в єдиний процес усю сукупність різноманітних і різнорідних операцій $з$ опредметнення людської ідеї. Інтенсивний розвиток техніко-технологічної сфери сучасних індустріально розвинених суспільств актуалізує проблему аналізу інженерної діяльності й управління цією підсистемою, яка, вириваючись уперед, породжує безліч проблем: від споживацького ставлення до біосфери до вторгнення в засади людського буття. Сучасний рівень розвитку інженерної діяльності показує, що вона радикально перетворює природу, суспільство й людину. Породжуючи комфорт, вона одночасно викликає непоправні, а часом трагічні наслідки в розвитку людської цивілізації. Необхідність у соціальнофілософському осмисленні інженерної діяльності залежить від того, що саме технічна підсистема (продукт інженерної діяльності) $є$ ключовою характеристикою у визначенні рівня розвитку сучасного суспільства. Потреби, стимули й мотиви пояснюють, як об'єктивна детермінація реалізується в процесі суб'єктивної інженерної діяльності, і постають власне механізмом цієї реалізації. Вихідним пунктом детермінації є об'єктивні умови життя людей, які породжують у них певні потреби й цілі, які трансформують об’єктивну детермінацію в суб'єктивну.

У визначенні аксіологічного аспекту інженерної діяльності слід ураховувати, що 
цінності - це атрибутивна характеристика будь-якої діяльності, істотний момент іiі соціального буття. Специфіка інженерної діяльності полягає в тому, що остання через своє функціональне призначення сприяє створенню технічних засобів для досягнення соціальних цілей. Інженерна діяльність є засобом реалізації креативності людини. Це означає, що через неї людина взаємодіє зі світом як суб'єкт і отримує можливість змінювати світ. Результатом діяльності постає трансформація природного в технічне, у якому знімається колишня природна форма речі або процесу. Об'єктами технічної діяльності $\epsilon$ перетворене людиною природне середовище та створення штучного середовища проживання - техносфери.

Існують дві групи факторів, що визначають розвиток інженерної діяльності. Перша група - ендогенні (внутрішні) закономірності, внутрішня логіка розвитку інженерної діяльності, пов'язана 3 розвитком технічного знання, яка зачіпає іiі субстанціальну сторону, іï елементи й структуру, дозволяє виокремити багато технічних закономірності, які виражаються в зміні матеріального субстрату, структури, функції - предмет аналізу інженерної філософії техніки. Друга група екзогенні (зовнішні) закономірності, зумовлені соціальними потребами й культурними особливостями - предмет гуманітарної філософії техніки. Ці закономірності визначають умови розвитку інженерної діяльності, загальну логіку їі розвитку. У процесі інженерної діяльності суб'єкт наділяє значенням найрізноманітніші предмети і явища, які постають цінностями як певні цілі або як засоби досягнення цих цілей.

У всіх випадках цінності постають мотивувальною й регулювальною засадами формування, розвитку потреб та інтересів суб'єкта, будучи детермінантами його діяльності. Гуманізація інженерної діяльності полягає насамперед у тому, щоб виробити механізми, які не дозволяють технічним об'єктам розширюватися на шкоду особистісним структурам людини й довкілля.

Техніцистське виховання в межах професійної інженерної освіти виробляє прагматичний стиль мислення. Траєкторія індивідуальної професійної й життєвої кар'єри фахівця інженерного профілю визначається мірою його ідентифікації 3 фундаментальними соціокультурними й світоглядними константами. Технократизм у період глобалізаційних процесів репрезентує прагнення звільнитися від влади природи й історії над людиною. Причому історія по суті і $є$ процесом звільнення людини як виду від влади природи, що має на увазі: а) адаптацію до природи як завдання-мінімум; б) власне звільнення від іi влади як завдання-максимум. Гіперраціональний стиль мислення суб'єкта інженерної діяльності, що створює «досконалу техніку», і відсутність системи позитивних цінностей у суспільстві становлять різноспрямовані динамічні вектори, що $є$ підгрунтям кризи сучасної цивілізації [5]. У сучасних українських умовах чітко проявляється світоглядна нестабільність у різних соціальних інститутах, включаючи освіту. Різка поляризація соціальної структури внаслідок швидкої соціальної диференціації, відсутність загальнонаціональної ідеї сприяють дезінтеграції суспільства й негативно позначаються на формуванні нового покоління інженерів. Починаючи з 1990-х рp., iз Заходу переймають не тільки форми господарювання, політичного устрою держави, 
але й саме світобачення, що охоплює вирішення проблеми людина - суспільство не на користь останнього [8].

Філософсько-соціологічний аналіз суб'єкта інженерної діяльності, зроблений у межах соціально-ціннісної концепції, передбачає дослідження позиційних модифікацій інженерів у структурі суспільства. Імпульсом для вивчення цих переміщень інженерів у соціальній структурі сучасного суспільства стали ідеї Т. Парсонса і Р. К. Мертона про структурно-функціональний устрій суспільства. У межах цього підходу інженерну діяльність розуміють як переплетення безлічі взаємодій людей [6]. Аналіз цих взаємодій відбувається в системі, у якій вони здійснюються, а починається він із пошуку інваріантних елементів щодо рухомого світу. Перерахування вимог, виконання яких потрібно для виживання системи, призводить до підсумовування їх у поняттях функціональної й структурної необхідності, оскільки функціонування структури має стійкий характер, саме поділ на структури й функції стає відносним [11].

Користуючись цією методологією, відповідно до функцій усередині інженерного корпусу можна виділити дві групи: 1) інженерів-розробників (або інженерів у вузькому сенсі слова) і 2) інженерів-організаторів (або господарських керівників різних рівнів). Для першої групи характерна переважно горизонтальна, а для другої переважно вертикальна кар'єра (соціальна мобільність). Сучасна інженерна діяльність розгорнута на новому соціальному просторі, яке часто називають постсучасністю. Ідеться не про принципово новий тип суспільства, а про новий етап розвитку капіталістичного суспільства. Постсучасність проявлена в стані бродіння, нестійкості, плинності, скепсису, іронії й нестабільності будь-яких відносин. Техніцизм постсучасності виявлений як декомпозиція всього органічно цілісного, а глобалізм - як послідовне дистанціювання від «місцевого» й аморальність як звільнення від соціального боргу та служіння.

Разом техніцизм і глобалізм породжують нинішні соціокультурні зрушення, які можна схарактеризувати як технократичні. Техніцистське виховання й технічна освіта не залишають у людини достатньо часу й сил для відповідного гуманітарного навчання, у результаті чого виявляється недорозвиненою емоційна сфера особистості й виробляється гіперраціональний, надпрагматичний стиль мислення. Насаджується культ доцільності, культ техніки призводить до спотворення людиною своєї сутності, до самоуподібнення людиною нею ж самою створеним комп'ютерам і роботам.

Траєкторія індивідуальної професійної й життєвої кар'єри фахівця інженерного профілю визначається мірою його ідентифікації 3 перерахованими вище фундаментальними соціокультурними та світоглядними характеристиками [2]. Професійний інженер живе й працює в суспільній системі й повинен розуміти особливості культурних, людських цінностей. Викладання соціально-гуманітарних наук майбутнім інженерам не можна розглядати як якусь гуманітарну «добавку» до їхньої освіти. Сьогодні гуманітарне виховання інженера конче потрібне, бо має сутнісне значення для визначення типу майбутнього. Ця проблема $\epsilon$ особливо актуальною у зв'язку з тим, що знижено державне регулювання багатьох суспільних процесів [2]. Процес формування ціннісних уявлень про професію в майбутніх 
інженерів $є$ перенесенням усередину їх особистості зовнішнього соціокультурного змісту (процес інтеріоризації). Цей процес $є$ не тільки засвоєнням особистістю культурного змісту, а й одночасно розкриттям нею своєї сутності, що є зовнішньою щодо конкретного соціокультурного середовища.

Соціально-ціннісна концепція інженерної діяльності охоплює розгляд соціальнопрофесійної мобільності як один із важливих механізмів суспільного відтворення групи інженерів. Дуже часто єдиним способом просування в інженерній професії $\epsilon$ перехід із власне інженерної професії в управлінську. Система якостей, що становлять підгрунтя інженерного таланту, не є підгрунтям для успішної діяльності в межах управлінської кар'єри. Вертикальна кар'єра інженера будується на підставі зовнішніх, суспільних орієнтирів і визначається ними. Вона передбачає залученість у соціальне середовище через систему професійних і громадських ролей. Фахівці з цим типом спрямованості - творці суспільного життя, живуть у злагоді з суспільно заданими зразками, мають схематичний образ довколишнього світу у зв'язку з тим, що сприймають його через громадські символи й знаки. Обираючи спосіб життя в професії, фахівець засвоює соціальні норми суспільства, пристосовується до його ієрархічної структури і грає за їі правилами, такий фахівець соціалізується за типом наслідування й настанови [1]. Горизонтальна кар'єра інженера - такий тип кар'єри, у межах якої людина будує й відтворює іiі в гармонії зі своїм життям в цілому, відповідно до внутрішніх схильностей i незалежно від того, схвалюється це суспільством або ні («не схвалюється» в цьому випадку не є синонімічним до «засуджується», а $є$ синонімічним до «не винагороджується»). Фахівець не приходить до згоди із соціумом, а сам привносить у соціум свої норми. Такий фахівець залучається до суспільства через увесь спектр наявних у суспільстві ролей.

Вертикальна й горизонтальна кар'єри інженерів схвалюються як два рівноправних способи життя в професії й суспільстві. Вони можуть доповнювати одне одного, різниця полягає в домінуванні тієї чи іншої цінності. Для прихильників вертикальної мобільності, що бажають посісти високий статус управлінців, спрямованих на рух угору за суспільно вагомими цінностями, світ досить схематичний, у ньому мало реальних речей, людей, у ньому все швидко змінюється й трансформується. У цілому група фахівців, яка обирає вертикальний тип кар'єри, характеризується технічним баченням світу з елементами гармонійності, знаковості, метричності. Ця модель становить собою урізану картину реального світу, який не містить людський і природний фактори, який передбачає, що люди схвалюються як споживачі дарів природи й виробники продукції, витоки якої перебувають також у природі.

Для фахівців із горизонтальною, внутрішньою спрямованістю середовище, у якому вони живуть, дуже часто наповнене живою природою, технікою, людьми. Техніка в середовищі такого роду існує нарівні з людьми, природою, інформацією й красою. Техніка є об'єктом, який підлягає експлуатації, удосконаленню й не більше за те. Таким чином, світ інженерів, схильних до горизонтальної мобільності, схвалюється більшою мірою як цілісний світ, гармонійний, наповнений технікою в першу чергу, а потім людьми, але все ж реальний, а не знаковий образ. 
Таким чином, усі наявні моделі аналізу інженерної діяльності умовно поділяються на інструменталістські, які розглядають «інженерну діяльність саму по собі», закономірності виникнення інженерної діяльності, етапи іiї розвитку, i соціогуманітарні, «інженерну діяльність для нас», що вивчають питання, як інженерна діяльність впливає на людину й суспільство. Існують також дві групи факторів, що визначають розвиток інженерної діяльності: ендогенні (внутрішні) закономірності, внутрішня логіка розвитку інженерної діяльності, пов'язана 3 розвитком технічного знання; екзогенні (зовнішні) закономірності, зумовлені соціальними потребами й культурними особливостями.

Сьогодні інженерна діяльність розгорнута на новому соціальному просторі, який у межах постмодерністської концепції позначається як постсучасність, де позитивна система цінностей не визначена.

Аналіз ціннісних уявлень про професію становить ядро соціально-ціннісної концепції інженерної діяльності. У формуванні професійної етики студентів усе сильніше проявляються елементи ринкової психології. Разом зі зростанням несприятливих наслідків техногенних ризикових процесів починає гостро усвідомлюватися тіньова сторона науково-технічного прогресу в цілому й інженерної діяльності зокрема. Процес формування ціннісних уявлень про професію в майбутніх інженерів $є$ процесом інтеріоризації. Цей процес характеризується не тільки засвоєнням особистістю культурного змісту, а й одночасно розкриттям нею своєї сутності, що є зовнішньою щодо конкретного соціокультурного середовища.

\section{Література:}

1. Воронянський О. В., Кулішенко Т. Ю. Влада як системний елемент економічних відносин: механізм відтворюваності //Вісник Харківського національного технічного університету сільського господарства імені Петра Василенка. 2016. №. 174. С. 109-117.

2. Воронянський $O$. Національна еліта сучасної України: проблема визначення // Українознавчий альманах. 2012. Вип. 8. С. 205-207.

3. Dessauer Fr. Philosophie der Technik. München, 1927. P. 66.

4. Heidegger M. Die Technik und Die Kehre. Pfullingen, 1962. P. 5.

5. Митчем К. Что такое философия техники? М., 1995. 120 с.

6. Мертон Р. К. Социальная теория и социальная структура. М., 2006. 230 с.

7. Mumford L. The Myth of the Machine. NewYork, 1967.Vol.1. P. 9.

8. Національний суверенітет: український вимір в контексті світової політичної думки / О. В. Воронянський, . С. Євсєєв, Ю.В.Журавльов, Ю. В. Зайончковський [та ін.]. Харків : «Міськдрук», ХНТУСГ імені Петра Василенка; ХНУБА, 2017.

9. Уэбстер Ф. Теории информационного общества. М., 2004. 284 с.

10. Ortega-y-Gasset J. Obras Completas. Midltawn, T. 1-6. 1957-1958.

11. Парсонс T. Система современных обществ. М., 1997. 


\section{Natalya Bondar, Oleksandr Osipov}

\section{SOCIAL-VALUE CONCEPT OF ENGINEERING ACTIVITIES}

All existing models for analyzing the goals and objectives of engineering activities can be divided into two groups. Instrumentalistic (or engineering), considering engineering activity from a technological point of view, and socio-humanitarian, considering the influence of engineering activity on a person and society, possible transformations that occur to a person as a result of the development of technical and technological sphere. The philosophy of technology in its instrumentalistic concepts represents, on the one hand, an attempt by technicians and engineers to develop the philosophy of their professional field. On the other hand, the philosophy of technology in social humanitarian concepts is a combination of the efforts of humanities scholars to comprehend technology as a subject of interdisciplinary reflections.

The purpose of this article is to examine the philosophical foundations of the sociallyvaluable basis of modern engineering activity in a post-industrial society.

Original works in this field have been published by both domestic and foreign authors: V. G. Gorokhova, B. I. Kozlova, P. Kozlowski, X. Lenk, N. M. Mamedova, K. Mitchchem, X. Ortegi-i-Gasset, A.N. Pavlenko, V. M. Rozina, M. A. Rozov, V.S .Stepina, P.A. Florensky, M. Heidegger, M. L. Shubas, P. Yanikh, K. Jaspers, and others.

The current level of engineering activity shows that it radically transforms nature, society and man. The need for a social and philosophical understanding of engineering activity is determined by the fact that it is the technical subsystem (product of engineering activity) that is a key characteristic in determining the level of development of modern society. Needs, incentives and motives explain how objective determination is realized in the process of subjective engineering activity and act as the mechanism of this realization. The starting point of this determination is objective living conditions of people, which give rise to their needs and goals, which transform objective determination into subjective. Thus, engineering activity, by virtue of its functional purpose, contributes to the creation of technical means for achieving social goals.

There are two groups of factors determining the development of engineering activities. The first group: endogenous (internal) patterns, the internal logic of the development of engineering activity, associated with the development of technical knowledge, which affects its substantial side, its elements and structure. The second group: exogenous (external) consistent patterns, caused by social needs and cultural characteristics - the subject of humanitarian philosophy of technology.

These patterns determine the conditions for the development of engineering activity and general logic of its development. The process of formation of value concepts about the profession of future engineers is the transfer of the internal socio-cultural content inside their personality. This process is not only the adoption of cultural content by a person, but at the same time it reveals its essence, which is external to a specific sociocultural environment. The process of formation of value concepts about the profession among future engineers is the transfer within their personality of external socio-cultural content (the process of interiorization). This process is not only the adoption of cultural content by a person, but at the same time it reveals its essence, which is external to a specific 
sociocultural environment.

\section{Наталя Бондар, Олександр Осипов}

\section{СОЦІАЛЬО-ЦІННІСНА КОНЦЕПЦІЯ ІНЖЕНЕРНОЇ ДІЯЛЬНОСТІ}

Усі наявні моделі аналізу цілей і завдань інженерної діяльності умовно можна поділити на інструменталістські, які розглядають інженерну діяльність із погляду технології, і соціогуманітарні, які розглядають вплив інженерної діяльності на людину й суспільство. Філософія техніки в їі інструменталістських концепціях $\epsilon, 3$ одного боку, спробою техніків і інженерів виробити філософію своєї професійної сфери. 3 другого боку, філософія техніки в соціогуманітарних концепціях $\epsilon$ сукупністю зусиль учених-гуманітаріїв осмислити техніку як предмет міждисциплінарних рефлексій.

Найбільш ефективний шлях аналізу сутнісних підстав інженерної діяльності звернення до традиції філософії техніки. Опубліковано оригінальні праці в цій галузі як вітчизняних, так і зарубіжних авторів, зокрема В.Г. Горохова, Б.І. Козлова, П. Козловського, Х. Ленка, Н.М. Мамедова, К. Мітчема, Х. Ортеги-і-Гассета, А.Н. Павленко, В.М. Розіна, М.А. Розова, В.С. Стьопіна, П.А. Флоренського, М. Гайдепера, М.Л. Шубаса, К. Ясперса та ін.

Мета пропонованої статті - розглянути філософські основи соціально-ціннісних засад сучасної інженерної діяльності в постіндустріальному суспільстві.

Сучасний рівень розвитку інженерної діяльності показує, що вона радикально перетворює природу, суспільство й людину. Необхідність у соціально-філософському осмисленні інженерної діяльності залежить від того, що саме технічна підсистема (продукт інженерної діяльності) $€$ ключовою характеристикою у визначенні рівня розвитку сучасного суспільства. Потреби, стимули й мотиви пояснюють, як об'єктивна детермінація реалізується в процесі суб'єктивної інженерної діяльності, і постають власне механізмом цієї реалізації. Вихідним пунктом детермінації $\epsilon$ об'єктивні умови життя людей, які породжують у них певні потреби й цілі, які трансформують об'єктивну детермінацію в суб'єктивну. Таким чином, інженерна діяльність через своє функціональне призначення сприяє створенню технічних засобів для досягнення соціальних завдань.

Усі наявні моделі аналізу інженерної діяльності умовно поділяються на інструменталістські, які розглядають «інженерну діяльність саму по собі», закономірності виникнення інженерної діяльності, етапи розвитку, і соціогуманітарні, «інженерну діяльність для нас», що вивчають питання, як інженерна діяльність впливає на людину й суспільство. Існують також дві групи факторів, що визначають розвиток інженерної діяльності: ендогенні (внутрішні) закономірності, внутрішня логіка розвитку інженерної діяльності, пов'язана з розвитком технічного знання; екзогенні (зовнішні) закономірності, зумовлені соціальними потребами й культурними особливостями.

Сьогодні інженерна діяльність розгорнута на новому соціальному просторі, який у межах постмодерністської концепції позначається як постсучасність, де позитивна система цінностей не визначена.

Аналіз ціннісних уявлень про професію становить ядро соціально-ціннісної 
концепції інженерної діяльності. У формуванні професійної етики студентів усе сильніше проявляються елементи ринкової психології. Разом зі зростанням несприятливих наслідків техногенних ризикових процесів починає гостро усвідомлюватися тіньова сторона науково-технічного прогресу в цілому й інженерної діяльності зокрема. Процес формування ціннісних уявлень про професію в майбутніх інженерів $є$ процесом інтеріоризації. Цей процес характеризується не тільки засвоєнням особистістю культурного змісту, а й одночасно розкриттям нею своєї сутності, що є зовнішньою щодо конкретного соціокультурного середовища.

Bondar Natalya Aleksandrovna - Candidate of historical sciences, associate professor of UNESCO department «Philosophy of Human Communication» and social-humanitarian subjects of Petro Vasylenko Kharkiv National Technical University of Agriculture.

Бондар Наталя Олександрівна - кандидат історичних наук, доцент кафедри ЮНЕСКО «Філософія людського спілкування» та соціально-гуманітарних дисциплін, Харківський національний технічний університет сільського господарства імені Петра Василенка.

e-mail: nbon79@gmail.com

ORCID: 0000-0003-3449-5884

Osipov Oleksandr Mihailovisch - Senior Lecturer of the Department of Social and Humanitarian Disciplines, Kharkiv National University of Construction and Architecture.

Осіпов Олександр Михайлович - старший викладач кафедри суспільногуманітарних дисциплін Харківського національного університету будівництва та архітектури.

e-mail: ukrcathedra2016@gmail.com

ORCID: 0000-0002-7853-1405

Надійшла до редакції 09.07.2018. Розглянута на редколегії 17.09.2018.

\section{Рецензенти:}

Доктор філософських наук, професор, професор кафедри суспільно-гуманітарних дисциплін Харківського Національного університету будівництва та архітектури Проценко О.П.

Доктор філософських наук, професор, головний науковий співробітник відділу гуманітарної політики Національного інституту стратегічних досліджень при Президентові України Степіко М.Т. 